\title{
Capitalism and Freedom: The Core of a Contradiction - An Essay on Cornelius Castoriadis and John McMurtry[1]
}

\section{by Giorgio Baruchello}

o.o Capitalism and freedom is not only the title of a 1962 book by Milton Friedman playing a pivotal role in asserting worldwide the neoliberal paradigm, but also the slogan that leading statesmen, politicians and opinion-makers have been heralding in recent years, in order to justify, amongst other things, the slashing of welfare states and the invasion of foreign countries. Often, "capitalism" has been rephrased as "free trade" or "free market",[2] and coupled regularly with "democracy", this term denoting the political system that is believed to better entrench and promote "freedom" or "autonomy".[3] Thus, capitalism and democracy have been described as the two sides of one and the same project for human emancipation, ${ }^{[4]}$ colouring the ideology and the political agenda of governments left and right, and showing how deeply neoliberal beliefs have become part of the dominant public mindset. Bill Clinton, for example, latest Democrat to be President of the United States of America, asserted:

Fair trade among free markets does more than simply enrich America; it enriches all partners to each transaction. It raises consumer demand for our products worldwide; encourages investment \& growth; lifts people out of poverty \& ignorance; increases understanding; and helps dispel long-held hatreds. That's why we have worked so hard to help build free-market institutions in Eastern Europe, Russia, and the former Soviet republics. That's why we have supported commercial liberalization in China-the world's fastest-growing market. Just as democracy helps make the world safe for commerce, commerce helps make the world safe for democracy. It's a two-way street.[5]

Whether the capitalist experiment promoted in the 1990s by Bill Clinton and Boris Eltsin in former Soviet Union has been successful or not is an issue that will not be

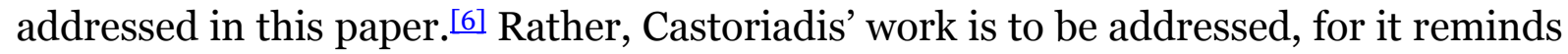
us of the fact that capitalism and democracy have had:

- A different historical-geographical origin ( $\S \S 1.0-1.2 .3)$, and

- A different orientation of value or defining aim (§§ 1.2-1.3.4).

As concerns these two points, the following paragraphs will present and discuss some of Castoriadis' teachings, sometimes directly, other times in connection with other thinkers. In particular, I shall endeavour to integrate Castoriadis' studies with John McMurtry's latest ones ( $\S \S 1.4 \mathrm{ff}$ ). ${ }^{[7]} \mathrm{My}$ aim is twofold. First of all, I wish to highlight the understanding of a contradiction between democracy and capitalism, already denounced in the past under many guises, yet from a perspective that is peculiar to Castoriadis. ${ }^{[8]}$ Secondly, I wish to introduce briefly some of the concepts developed by 
one of today's most original critics of neoliberalism, i.e. the Canadian thinker John McMurtry, whose work is still little known in northern Europe. ${ }^{[9]}$ His work, in my view, does not solely reinforce Castoriadis' critical analysis, but fleshes out more profoundly the axiological divide placed between capitalism and a truly lifeenhancing democracy. Depending on the reader's knowledge of the matters discussed, my essay is bound to be situated between the two extremes of redundancy and insightfulness. $\frac{10]}{}$ Whichever be the case, I shall have complied with the mission of the Nordic Summer University, for which my essay is primarily intended, as it aims at "introducing new thinking and influences into the Nordic Countries."[11]

o.1 Terms such as "capitalism" and "neoliberalism" are often left undefined. In order to reduce the scope of possible ambiguity and misunderstanding, I wish to provide a clearer connotation of what is meant with "neoliberalism" in this essay by means of a critical summary outlining its main tenets. ${ }^{[12]}$ Some of these tenets are shared by liberal or classical economics as well; others, highlighted with an asterisk, are typical of its $2 \mathrm{O}^{\text {th }}$-century renaissance qua neoliberalism:

- All value is ultimately understood as, or reducible to, moneycapital; hence the neoclassical equation between prices paid for commodities and satisfaction of preferences, whatever they may be. Pareto's ophelimity, a standard presupposition of the neoclassical paradigm, does not distinguish qualitatively between the want of golden toilet seats and the need for potable water

- The maximisation of money-capital returns from invested money-capital is regarded as natural (i.e. an anthropological datum already endorsed by Adam Smith), rational (i.e. not to follow this principle is insane) and it can even be normatively binding (e.g. corporate managers have a 'fiduciary duty' before shareholders to the maximisation of their returns)

- No limit to the maximisation of such returns is set, as revealed by the neoclassical principle of non-satiety-a reformulation of Say's law in classical economics

- This maximisation is believed to be accomplished most effectively through a system of free sale and purchase of commodities i.e. the 'free market' commended already by Adam Smith

- The free market is believed to guarantee the fairest distribution of commodities, i.e. their 'optimal allocation', approaching an ideal balance between supply and demand, thanks to its alleged ability to self-adjust and regulate. Adam Smith regarded this ability as divine, for a Providential 'invisible hand' was said to make it possible for the pursuit of individual self-interest to become the origin of collective well-being i.e. the 'wealth of nations'

- It is inferred from the previous point that the public authority should interfere as little as possible with the free market, whether by means of taxation, subsidy or public ownership of assets that could be privately owned 
- An exception is made for those interferences that are deemed to serve the free market, thus ultimately leading to the paramount goal, i.e. maximisation of money-capital returns. Adam Smith, for example, regarded progressive taxation of income and the public provision of both domestic and international security as necessary to the wealth of the nations

- Since all value is ultimately understood as, or reducible to, money-capital, then the free market is regarded as the source of all that is valuable hence good and desirable

- Whenever undeniably negative effects are produced by the free market (e.g. carcinogenic pollution, life-threatening obesity, sexual exploitation), then these effects are either discarded as 'externalities' (i.e. the causal connection between the free market and its effects is nominally reduced) or accepted as 'unavoidable costs' that the alleged market's self-adjusting and regulating ability is bound to resolve*

- Since the free market is regarded as the source of all that is valuable hence good and desirable, those who criticise or threaten it are condemned as either irrational (e.g. incompetent, unscientific, ignorant) or evil (e.g. terrorist, communist, anarchist)*.

1.o Castoriadis teaches that the earliest forms of democracy were toyed with by several Greek city-States and communities in pre-Christian antiquity. ${ }^{[131}$ Further experiments saw the light in Continental Europe "at the end of the Middle Ages, ${ }^{[14]}$ in the interstices of the feudal world, [when] communities that wanted to be selfgoverned collectivities were reconstituted-new cities or bourgeois communes, in which a protobourgeoisie (long before any idea or real existence of capitalism!) $[5]$ created the first seeds [germes] of modern democratic and emancipatory movements."[16]

Additionally, Castoriadis teaches that these experiments in democratic rule were meant to guarantee the citizen's liberty from tyrannical rule, hence reducing the space for alienation, since they were aimed at establishing societies in which was granted to individuals and groups "the possibility of and the capacity for calling the established institutions and significations into question." "[ir] This was no small feat, for such openness to critical self-scrutiny and reconfiguration has represented, according to Castoriadis, "a tiny exception in the history of humanity."

On its part, capitalism, though anticipated in late medieval southern Europe, flourished only in modern northern Europe, particularly in Britain, and was such that: "All human activities and all their effects", hence politics as well, "c[a]me to be considered more or less as economic activities and products, or, at the very least, as characterized and valued essentially through their economic dimension. No need to add that this valuing is done solely in monetary terms." ${ }_{200]}$ As a consequence of this value orientation or defining aim, capitalism selects for/against that which is monetarily valuable/dis-valuable and, a fortiori, that which is/is not computable in monetary terms. 
1.1 Castoriadis recognises that many capitalist "societies include a strong democratic component. But the latter has not been engendered by human nature or granted by capitalism or necessarily entailed by capitalism's development. It is there as residual result, as sedimentation of struggles and of a history that have gone on for several centuries."[21] Were we even to concede that, in its expansion in modern times, the capitalist axiological revolution was accompanied throughout by an affirmation of democratic forms of government, this hypothetical datum would not diminish or contradict the fact that the attribution and active pursuit of monetary value is not the same thing as, nor is logically implied by, "the possibility of and the capacity for calling the established institutions and significations into question." ${ }_{22]}$ Capitalism and democracy, read through Castoriadis' lenses, are plainly two very different entities. Not only the "rights and liberties" celebrated in liberal, democratic constitutions, "did not arise with capitalism, nor were they granted by the latter."[24] Also, their defining orientation of value has been too divergent to be necessitated by capitalism. For Castoriadis: "Capitalism as such has nothing to do with democracy": whereas the latter aims at autonomy, the former aims at money-making-a point to be unpacked further in the following paragraphs. ${ }^{[25]}$

1.1.1 The geographically-located historicity of capitalism is not a new theme or realisation. Castoriadis cites Saint-Simon and Comte as enthusiastic supporters of the industrial revolution, genuinely aware of the novelty of the economic system that they commended to their fellow Frenchmen. For that matter, Adam Smith himself, the intellectual ambassador par excellence of modern capitalism, had already observed and studied the particular and unique "events"-his choice of words-making it possible for the new economic system to develop. ${ }^{[26]}$ Indeed, in his "Digression concerning the Variations in the Value of Silver during the Course of the Four last Centuries", Smith divided the history of modern Europe in three periods, explaining how "the market of Europe has become gradually more and more extensive" and why "since the discovery of America, the greater part of Europe has been much improved." "[27] As concerns the different nature of capitalism and democracy, Adam Smith never suggested that free trade would translate necessarily into democratic regimes-in which, to be true to his thought, he did not place his trust wholeheartedly.[28]

1.1.2 Adam Smith was a liberal, not a republican-in the $18^{\text {th }}$ - and $19^{\text {th }}$-century sense of these terms, far too often neglected, if not even forgotten. by today's scholars.[20] Yet, if one wishes to understand what "liberalisation" may signify, then one should look into the history and the meanings of "liberal". And for the Scottish liberal Smith, "democracy" meant to enlarge slightly the franchise for political participation amongst the "race of proprietors", who would have therefore seen the order of "those who live by rent" joined by the order of "those who live by profit". ${ }_{[30]}$ At the same time, the "race of labourers", namely the vast majority of the Earth's population, was to be left in a state of subjection. [3i1 This state of subjection being such that: "in civilized society it is only among the inferior ranks of people that the scantiness of subsistence can set limits to the further multiplication of the human species; and it can do so in 
no other way than by destroying a great part of the children which their fruitful marriages produce."[⿰氵32] Whenever the "real wealth of society becomes stationary" and eventually "declines... there is no order that suffers so cruelly from its decline... than that of labourers." "[33]

Life-destructive as it may have been, Smith saw no alternative to this state of affairs, upon which relied the whole economic system unfolding in Britain in his lifetime and, a fortiori, British society at large. After all, according to him, there was hope that the pursuit of private profit could prevent the real wealth of society from ever declining, if left unhindered and guided by God's "invisible hand". .344 On the contrary, there was no hope whatsoever for the "race of labourers" to aspire to actual political participation:

\begin{abstract}
But though the interest of the labourer is strictly connected with that of the society, he is incapable either of comprehending that interest, or of understanding its connection with his own. His condition leaves him no time to receive the necessary information, and his education and habits are commonly such as to render him unfit to judge even though he was fully informed. In the public deliberations, therefore, his voice is little heard and less regarded, except upon some particular occasions, when his clamour is animated, set on, and supported by his employers, not for his, but their own particular purposes.[35]
\end{abstract}

Much more bluntly than most of today's followers of his doctrine, Smith admitted that "Civil government, so far as it is instituted for the security of property, is in reality instituted for the defence of the rich against the poor, or of those who have some property against those who have none at all." "[66] And from the fact that Adam Smith never criticised either the private pursuit or the public defence of property via civil government, one can easily infer that he was not planning or promoting any major change in these matters. ${ }^{[3]]}$

1.1.3 I have dwelled on the case of Adam Smith because it is extremely significant, as he remains a major point of reference for today's neoliberals. In this perspective, Adam Smith is much more significant than Karl Marx, whose work finds a direct and patent echo in Castoriadis' own activities as a Trotskyite partisan, a social scientist, a philosopher, and a psychoanalyst. Critical at times, accommodating at others, Castoriadis retrieved in Marx "the robust awareness of the historicity of this phenomenon," i.e. the affirmation of capitalism, then dishonestly and "quickly covered over by the apologists for the new regime, who were recruited especially among the economists." started to wane, a "denial of capitalism's historicity" appeared on the scene, which "has prevailed among the economists from David Ricardo until the present day.[39] Political economy as well as its object have been glorified as an investigation into 'the pure logic of choice' or as a study of 'the allocation of limited means for the achievement of unlimited objectives" ",400] which has abstracted the historical, sociocultural and geographical reality of the actual economies observable in the World and turned them into impalpable fictions translatable into mathematical terms. ${ }^{[41]}$

Marx had witnessed the same phenomena as Smith, though on a much larger scale, since the capitalist machinery described in The Wealth of Nations was then affirming itself worldwide, no longer solely in Great Britain and its colonial empire. Marx too regarded the discovery of the Americas as a unique, crucial event, which had made it possible for the process of "primitive accumulation" to be ignited-this process being 
geographically and historically specific and, as Castoriadis writes, "conditioned by factors that have nothing 'economic' about them and that owe nothing to 'the market': specifically, extortion, fraud, and violence, both private and state-led."[42] Aware of these factors, Marx desired ardently to achieve a new social order whereby to guarantee the citizen's freedom to the fullest extent, quantitative as well as qualitative ${ }^{[43]}-$ a goal that Castoriadis, unlike Smith, shared with Marx throughout his adult life. For Castoriadis and Marx, "the possibility of and the capacity for calling the established institutions and significations into question" meant the departure from an economic and social reality condemning the majority of the world's population to de facto legal subjection, precariousness of livelihood, and utter political impotence. ${ }^{441}$ After all, according to Marx's analyses, it was exactly what the workers' discontent revealed: the masses-the demos-were not served well by capitalism, contrarily to what Smith indicated. Thus, as known, Marx tackled the element that Smith claimed to be residing at the core of the economic and social arrangement allowing for the vast majority of the world's population to depend on wages for their survival: property. ${ }^{[45]}$

1.1.4 Whether Marx's attempt was successful or not, it is too complex an issue to be discussed here. ${ }^{466]}$ Similarly, I am not interested in discussing the differences between Marx's top-down, State-centred communism and Castoriadis' bottom-up, selfmanaging system of social ownership. Rather, I shall limit myself to mention how Castoriadis, moving his analysis from another angle, criticised in the early 1990 s the dominant neoliberal mantra saying-much more vocally than ever after the fall of the Berlin Wall-that the "capitalist society" has "proved its excellence-its superioritythrough Darwinian selection." "447] According to Castoriadis, any serious historical study would show the pointlessness of using such a simplistic notion in order to make sense of the development of capitalism, and he mentions several authoritative intellectual figures substantiating his remark: "Max Weber... Werner Sombart... Richard Tawney... Karl Polanyi." ${ }_{488]}$ This issue is relevant to him because the Darwinist justification of capitalism would attain a terrifying threefold rhetorical goal:

- It would attribute some sort of historical necessity to the advent of capitalism, thus emptying whatever value human autonomy may have in these matters

- It would state this historical necessity in apparently rational, scientific terms, thus casting the shade of irrationality and "unscientificity" to any alternative economic system

- It would imply an overall positive evolutional evaluation of the same phenomenon, thus accusing any alternative economic system to be contrary, whether intentionally or not, to the very survival of the human species

For Castoriadis, contra the neoliberals, "applying the Darwinian schema to social forms in history" constitutes an "absurdity... and the repetition of the classic fallacy (the survival of the fittest is the survival of the fittest to survive; the domination of capitalism shows simply that it is the strongest, ultimately in the crudest and most 
brutal sense of this term, not that it would be the best or the most 'rational')."[49] Moreover:

What one observes in the sixteenth, seventeenth, and eighteenth centuries is not a competition among an indefinite number of regimes, out of which capitalism would have emerged the victor, but the enigmatic synergy of a host of factors that have all conspired toward the same result. That, later on, a society founded upon a highly evolved technology might have been able to show its superiority by exterminating Amerindian nations and tribes, as well as Tasmanian or Australian aborigines, and by enslaving many others, presents no great mystery.[50]

Besides, if we were to take seriously the application of Darwinian selection to human societies, then the next Genghis Khan, Stalin or Osama bin Laden that were resolute, fortunate and merciless enough to reshape the face of the planet would prove the superiority of his nightmarish New Order.511

1.1.5 We find an echo and a refinement of this point in McMurtry's claim that "evolutionary theory's primary value of 'fitness to survive' has become a kind of universal assumption of science, economics and the public mind. Unfortunately, what is missed by propagation of this idea of the good are its vicious implications." [52] Whereas Castoriadis focuses primarily on the application of the Darwinian schema to the historical affirmation of capitalism in the modern era, McMurtry writes mostly about its ecological effects, current as well as future. In both cases, the result is a picture of the socio-historical application of the Darwinian schema that ought to sound paradoxically amoral and life-denying. Specifically, if "it is assumed ex hypothesi that such a species is the 'fittest' or 'most successful' with the 'most favourable characteristics' because of its most numerous reproduction through time", then "its destructions of other life forms pose no issue within this thought frame". 553$]$ As a consequence, "this regulating value system can, it follows, lead to a world denuded of every other species, with the dominant species' dog-eat-dog competition among its own members duly selecting for moral monsters: that is, beings which only multiply themselves at the expense of other life and towards the total occupation by their progeny and descendants of the world and its life means." "554 Rather than securing life on a planetary scale, "the outcomes of such 'fitness to survive'," turned into the unseen value-framework of human activities, "do not demonstrate goodness or excellence, as the concepts 'fitness' and 'favourable characteristics' suggest, but a progressively virulent corruption of the dominant species and the homogenizing degradation of terrestrial life itself. What is thought to be 'evolutionary advance' can come to be the opposite."[55]

1.2 The "dog-eat-dog" pursuit of wealth displayed by capitalism is nihil novum sub sole. Castoriadis observes that empire-building as well as "hoarding [have been] practiced in many historical societies, and attempts by latifundist landowners to exploit the land on a grand scale with servile labor are also known (in particular, during a period close to us, in imperial Rome)."[56] What is specific to the capitalist type of accumulation is "the continual transformation of the production process with a view toward increasing output, combined with a reduction of costs."[57] Capitalism aims at maximising profit by increasing revenues and reducing costs-what is taken 
nowadays to be the standard for rationality itself. ${ }_{.58]}$ According to Castoriadis, "that is the decisive feature. This characterization contains the basics of what Weber would later call 'rationalization,' and about which he will say, correctly, that under capitalism it tends to seize hold of all spheres of social life, doing so in particular as an extension of the empire of calculability."[50] In this process, "Capitalism [becomes] a regime that cuts off virtually every relationship between the institution and an extrasocial instance of authority. The sole instance of authority it invokes is Reason, to which it gives a quite peculiar content."[60] Anything that contradicts this peculiar form of "enlightened" imperialism, ${ }^{[61]}$ which sheds oblivion's dimmest darkness on any alternative form of reason, ${ }_{[62]}$ is blamed as "irrational", "sentimental", "utopian", "out of date", "standing in the way of progress" or, if insistent, as "threats to law and order": there is no lack of rationalisations for the capitalist standard of rationality. ${ }^{[63]}$ In this fashion, capitalism embodies "one of the most deep-seated traits of the singular psyche-the aspiration to omnipotence."[64]

1.2.1 Concerning omnipotence, Feuerbach had already suggested in the $19^{\text {th }}$ century that religion arose from humankind's dream of omnipotence. Specifically, as this dream got continuously frustrated by reality's resistance to human will, humankind began a process of self-alienation, at first individuating spiritual entities in nature to be "bought" with sacrifices and rites, and then reaching the ascription of absolute omnipotence to an utterly superior God, thus leaving humankind powerless. Humankind, in other words, alienated herself of her own world-changing powers by projecting them all onto a divinity that humanity herself had generated. ${ }^{[65]}$

John McMurtry, in the $21^{\text {st }}$ century, suggests that classical (or liberal) and neoclassical (or neoliberal) economics have led many governments and human communities along analogous lines of self-alienation. Specifically, given the governments' alleged inability to sustain or even bring about the much-desired common good or "social optimum", classical economists started positing "a doctrine of unintended consequences" whereby "the perfect orchestration of countless changing factors" is guaranteed "by the apotheosized Market Hand" and such that "the causal sequence is predestined without human reason involved".[66]

On the contrary, human involvement started being blamed as undue interference, and later even condemned as the "road to serfdom" (the title of a well-known volume by neoclassical "giant" F. A. von Hayek). Markets have to be left to themselves, whereas governments should shrink in size, whilst States become aggregations of individual consumers rather than cooperating citizens, eventually leaving entire human communities with hardly a shred of planned economic policy aiming at the much-desired common good. Instead, this good should come about automatically, handed down by a perfectly self-organising combination of market forces, which are assumed to deliver it at some later point. ${ }^{67]}$ Thus, no evidence can count as counterevidence, for the basic assumption of "social optimum" developing from "private greed" is not falsifiable: one must simply wait and apply more nonintervention in order for the mathematically-expressed most favourable equilibria to be reached. ${ }_{\text {.68] }}$ Capitalism, under this description, is not only the actual master of our collective fate; it ought to be this master. 
1.2.2 "This tendency, this push toward mastery," Castoriadis emphasises, is not "something exclusively specific to Capitalism."[60] Rather, with capitalism, "this push toward mastery is not merely oriented toward 'foreign' conquest but intends just as much and still more the totality of society... education, law, political life, and so on."[zo] Pervasive and decisive, the value orientation of capitalism is tyrannical, for it aims at controlling every aspect of human life, so as to increase efficiency of output.[7] Anything that escapes it is a waste, a missed business opportunity, an obstacle to be overcome, if not even a potential threat. Thus, whereas democracy has typically implied pluralism and indeterminacy of ends within a basic constitutional framework, ${ }^{[2] 2]}$ capitalism cannot support them, for there can be only one economic system, driven by the goal of the maximisation of profit-indeed, today's "navigators" of business enterprises are said to have a "fiduciary duty" to this end.[731 As McMurtry puts it, "The market God is, above all, a jealous God. No other economic idea may be put before it."

Consistently with its tyrannical tendency, Castoriadis claims that capitalism's "push toward mastery gives itself new means-means of a special character ('rational,' that is to say, 'economic' ones)... [such as]

- The blossoming of science...

- The birth and the consolidation of the modern State...[z5]

- The formation of modern nations."[-[6]

- Moreover, a fourth means comes into play: a new mindset.

As denounced already by Edmund Burke, surely not a revolutionary or a radical thinker, in the feudalism-abandoning Europe "economic motivation tended to supplant all other motives. The human being became homo oeconomicus, that is to say, homo computans." "[z] Throwing away centuries of wisdom as well as superstition, "all the decent drapery of life is to be rudely torn off" in lieu of a novel age "of sophisters, economists, and calculators" annihilating "that generous loyalty to rank and sex, that proud submission, that dignified obedience, that subordination of the heart, which kept alive, even in servitude itself, the spirit of an exalted freedom." $[$ [78] It is not relevant to inquire in the extent to which Burke's depiction of the Middle Ages, its diffuse sense of fealty, and its peaks of civil gentlemanship and religious piety is accurate. Rather, it sheds light on the homo novus of the early capitalist age, who calculated that it was appropriate to challenge the existing legal and political institutions in the name of democracy (as the Frenchmen dreaded by Burke had done with ample shedding of blood); for it is only in this perspective, i.e. as an instrumental relationship, that capitalism chose-in addition to science, statehood and nationhood-"the resumption of the ancient movement toward autonomy" i.e. the means of democratic rule.[70]

1.2.3 Constrained by the pre-existing feudal institutions, this resumption "manifested at the outset as a protobourgeois movement whose intention was to establish the independence of the commons," becoming later a properly bourgeois movement capable of calling into question the existing political and legal structures 
and of reshaping them to its own end and purpose. ${ }^{800]}$ However, as a self-aware expression of human creative freedom capable of critical activity, democracy can no longer be appreciated by capitalism, once the latter is firmly established. As soon as no alternative economic system is left on the scene, the memory and the possibility of human creative freedom capable of critical activity concerning economic systems must be erased, so that "capitalism's domination of the modern era does not appear then as what it is-namely, arbitrary creation of a particular humanity-but as fated phase of all historical movement, at once fated and welcome."[81]

Like Galileo's new science, the first centralised, bureaucratically-cohesive, nationallydefined Western States appeared on the scene before any mature bourgeoisie, i.e. around the $17^{\text {th }}$ century (i.e. the "Westphalian" State). These States, run by absolute monarchies and filled with feudal significations and institutions, fought against the protobourgeois democracies of their time and forced them into oligarchic retreat. Yet, the later industrial-financial bourgeoisie of Europe seized hold of these significations and institutions and used them to pursue its ends. The relationship of capitalism to science, modern statehood and nationhood is, like that to democracy, extrinsic, and specifically instrumental. The intrinsic character of capitalism is not scientific, Statecentred, national, or democratic: it is economic or profit-centred. Were the circumstances to change, the relationship to these four instruments could change and, as a matter of historical fact, has changed.

Contemporary capitalism, for example, has opposed unprofitable science (e.g. early versions of electric cars, research suggesting the dangerousness of GMOs, the teaching of humanities inside universities), modern States (e.g. via global free movement of financial capital, subtraction of resources by siphoning revenues to fiscal havens, blackmailing governments by off-sourcing threats), nationhood (e.g. by marketing international standardised dress codes, promotion of English as the World's lingua franca, continued pressure for international integration), and democracy (e.g. by enmity to tax-centred egalitarian redistribution of wealth, political lobbying for intervention into countries where socialist governments were democratically elected, superseding popular representation by supranational trade agreements).

1.3 Here is the heart of the critique of Castoriadis. Despite all the a posteriori claims of inevitability, capitalism and democracy arose together in modern times contingently and their marriage is far from being a smooth, serene one.

First of all, "the adoption of capitalism does not entail a liberal political regime-as Japan shows us... from 1860 to 1945 , or South Korea after the war."[882] Not only were there democratic experiments prior to capitalism (Castoriadis as a Greek, and myself, a Genoese, are most aware of this fact), but the latter made use of the former because it was instrumental to the achievement of its goals in certain historical contexts.

Secondly, even in those contexts, as soon as these goals were realised, democracy turned into a secondary matter, if not even a nuisance, an impediment, a menace to further profits. One must simply recall the fierce resistance that liberal States posited against "the resumption of the ancient movement toward autonomy... in the various species of the democratic and workers' movement" in the late $19^{\text {th }}$ century and in the first half of the $20^{\text {th }}$. ${ }_{\text {[83] }}$ Paupers, women, and various ethnic "minorities"[84] had to fight 
long and hard for the recognition of those basic civil and legal rights that the bourgeoisie had extorted from the ruling class of the ancien régime, one or even two centuries before them. ${ }^{[85]}$

Thirdly, the result of these prolonged struggles has not been full-fledged democracy, rather, as the liberal Vilfredo Pareto had already denounced one century ago, "regimes of liberal oligarchy [i.e.] the compromise our societies have reached between capitalism properly speaking and the emancipatory struggles that have attempted to transform or liberalize capitalism."[86] Such regimes foster democratic autonomy in proportion to its ability to serve capitalism. As Castoriadis writes: "In the effectively actual social-historical reality of contemporary capitalism, these [democratic] liberties function more and more as the mere instrumental complement of the mechanisms that maximize individual 'enjoyments' [jouissances]. And these 'enjoyments' are the sole substantive content of the 'individualism' being pounded into our heads these days"; as though, I must add, the citizen and the consumer were identical..87]

1.3.1 Friedrich August von Hayek and Ayn Rand, two pivotal figures in promoting the neoliberal paradigm during the $20^{\text {th }}$ century, did have some good reasons to argue that the civil and political freedoms of the liberal tradition were significantly related to the economic freedoms commended by the classical economists. Individual selfaffirmation, for example, can well express itself through entrepreneurial activity, whilst the interconnected global world of 'free trade' creates opportunities for selfexpression previously not available to the individual. Also, successful entrepreneurial activity implies certain forms of freedom, such as: degrees of unhindered intellectual research and circulation of technical or even scientific-technological information; reliable and possibly capillary transportation networks; opportunities for independent judgment and autonomous activity. Moreover, two parallel insights characterise political liberalism and economic capitalism, i.e. that the individual (political as well as economic) may know best what should be done in order to pursue her self-interest; and that a society where successful enterprises flourish is likely to be a prosperous society, analogously to the society allowing its individual members to pursue their life-plans unimpeded. However, given the value of these reasons, there still appears to be no essential link between political liberalism and classical economics, and history has repeatedly shown how this is the case. Besides, political liberalism, though democratic to some relevant extent, is not the only form of democracy possible, nor does it guarantee a priori the highest degree imaginable of popular self-determination, which Castoriadis takes as the defining element of democracy.[88]

1.3.2 Another way to cast this divergence of value was identified by Immanuel Kant in his Groundwork of the Metaphysics of Morals: "In the kingdom of ends everything has either a price or a dignity. What has a price can be replaced by something else as its equivalent; what on the other hand is above all price and therefore admits of no equivalent has a dignity. What is related to general human inclinations and needs has a market price; that which, even without presupposing a need, conforms with a certain taste, that is, with a delight in the mere purposeless play of our mental 
powers, has a fancy price; but that which constitutes the condition under which alone something can be an end in itself has not merely a relative worth, that is, a price, but an inner worth, that is, dignity." ${ }^{80]}$ By valuing human beings merely as means to an end, i.e. the creation of profit, and indeed as commodities for profit (e.g. the market labour), capitalism does not acknowledge the intrinsic worth of the human being, which democracy, for Kant and many other democratic thinkers, aims at enshrining within a just legal framework securing their political freedom.

Castoriadis shares with Kant and, for that matter, with Marx, the desire to guarantee the conditions that may allow all human beings to be valued as ends in themselves and enjoy real opportunities to cultivate their faculties in the non-harmful directions chosen by each freely, i.e. autonomously. Castoriadis' acceptance of Marxism and, at the same time, his criticism of Marxism, not to mention his rejection of Stalinism and Real Socialism, are motivated by the fact that socialist policies, variously interpreted and implemented, can move in the desired direction, but also in the opposite one. Analogously, Castoriadis' critique of capitalism, especially in its contemporary consumerist expression, is born out of the conviction that the tyrannical, constitutive pursuit of profit works against individual and social autonomy, whenever this autonomy may be employed in unprofitable ways (e.g. by privileging full employment over efficiency as prime target for the State's economic policy, public green areas to privately-contracted high-density urban development, welfare-enhancing redistributive fiscal policies to socially-polarising fiscal minimalism, non-consumerist enjoyment of leisure time over the purchase of leisure opportunities through pricedgoods and services). Whenever profitability is at issue: "capitalism has need not of autonomy but of conformism."[00]

1.3.3 Karl Marx argued that capitalism digs its own grave by producing continuous revolutions that cannot control. One of these revolutions, the proletarians', will burst capitalism asunder. Castoriadis agrees with Marx on the self-defying character of capitalism which, historically, did promote democracy as "the possibility of and the capacity for calling the established institutions and significations into question," yet opposing it when democracy began contradicting the in-built founding principle of the novel economic system, i.e. the pursuit of profit. Seen from Castoriadis' angle, democracy is capitalism's short-circuit, not the "two-way street" commended by Bill Clinton; it is a double-edged knife that served capitalism to cut ties with feudal Europe, yet can be used by capitalism's victims to chop the capitalist's head. Whether this "regicide" will ever happen, however, it is up to human communities. "For as a productive/economic system, capitalism is not exportable just like that, and the liberal-oligarchic regime, fallaciously called democracy, is not exportable, either. No immanent tendency pushes human societies toward all-out 'rationalization' of production to the detriment of all else, or toward political regimes that accept certain overt forms of intestine conflict while securing certain liberties. Historical creations, these two forms [capitalism and democracy] have nothing fated about them."[91]

Indeed, on a more specific note, Castoriadis claims that contemporary capitalism is destroying the two anthropological conditions that have made it possible for capitalism to affirm itself in modern times. On the one hand, the worldwide affirmation of the neoliberal agenda has been weakening trade unions and workers' 
associations, i.e. the main source of the "social and political struggles" that have corrected capitalism's self-destructive quest for omnipotence, exemplified by the ominous post-1929 global crisis, and brought about some mitigating, corrective mechanisms (e.g. Keynesian countercyclical State intervention and politicallydecided regulation of international currency flows). ${ }_{\text {.92] }}$ On the other hand, the consumerist society promoted by the same agenda has been erasing the pre-capitalist "series of anthropological types [capitalism] did not create and could not itself have created: incorruptible judges, honest Weberian-style civil servants, teachers devoted to their vocation, workers with at least a minimum of conscientiousness about their work, and so on." "[93] Also, with the growth of virtual economy above and beyond the real economy, it is also demolishing the only true capitalist anthropological type, i.e. "the Schumpeter-style entrepreneur".041 In lieu of these types, contemporary capitalism has contributed to the generation of the eternal teenager, stupefied by endless adverts and focused only upon the satisfaction of her selfish, shallow impulses; as well as the regeneration of the Weberian ruthless "pirate", whether in the form of financial speculators, self-serving top managers, or Sicilian Mafiosi and Colombian drug lords. 051

1.3.4 Yet not only is the neoliberal coupling of capitalism and democracy not natural; capitalism as such, contrarily to what many neoliberals may say, is not natural either. As Castoriadis observed, "almost the totality of human history has unfolded within regimes where economic 'efficiency,' maximization of the 'product,' and so on were in no way the central bearings for social activities." "[66] The liberal and neoliberal alleged anthropological data of self-maximisation and non-satiety have very little to do with most recorded human life: "almost always, on a given technological level, social life unfolds with a wholly different set of preoccupations than that of improving the 'productivity' of labor through technical inventions or through rearrangements of work methods and production relations."[07] Even if there may have been almost always a merchant class, some degree of financial activity, and various forms of private accumulation of wealth, "those sectors of social activity were subordinated to and integrated within others that were considered, each time, to embody the main finalities of human life." ${ }_{088}$ Anyone who walks into the Scrovegni Chapel of Padua, gloriously decorated by Giotto's frescoes, can sense the guilt of wealthy medieval merchants attempting to purify themselves from the sinful filth of money-making, as their economic existence was a fragment of a larger personal and social setting, i.e. their Christian life.[09]

Certainly, things are very different today, as the same anthropological data seem to depict the motivations and the aspirations of a conspicuous part of the world's population. Rappers walking out of fancy SUVs and pop singers commending money, sometimes above love itself, may well be the popular manifestation of this mindset.[100] Still, according to Castoriadis, even this popularity constitutes no valid substantiation of the liberal and neoliberal assumption of their naturalness, for "the justification is circular. In the 'wealthy' countries, people 'want' these [consumer] goods because they are raised from their tenderest years to want them (go visit an elementary school today, if you doubt it) and because the regime prevents them, in a thousand and one ways, from wanting anything else."[101] The tyrannical "free market" conditions the 
subject from cradle to grave, as any market expert would state candidly and shamelessly, , 102$]^{2}$ causing people to mistake artificially-instilled cravings for actual needs. ${ }^{1031}$ Then it sets these people "free" in the happy realm of consumer sovereignty, where they are trained to measure their worth by what they appear to be able to afford, analogously to the $14^{\text {th }}$-century parish priest educating the child to be a good Christian, certain that the psychological pressure of his parishioners would then keep her on the straight path for the rest of her life.[104]

John Kenneth Galbraith had already commented on this perplexing issue in the 1970s, while the pervasive means of indoctrination, or Sorelian "system of signs", manufactured by the medieval Church, Mussolini's Italy, and Stalin's Soviet Union found their modern analogue as the sophisticated bamboozling by scientifically crafted "advertising" and omni-pervasive media strategies aimed at "managing the behaviour of the consumer" in capitalist societies.[1051 This bamboozling runs deeper than the artificial instillation of desire to conformity/distinction qua perceived need, whether for the enjoyment of the purchased good per se or of the status it supposedly guarantees. ${ }^{[106]}$ It is by bamboozlement that the near totality of the system of signs itself is enforced and reinforced, which ascribes utility-absolute as well as marginal-to priced goods and services conferring status to those who own it and making those who do not contemptible or pitiable (Veblen's "pecuniary standard of decency").[107] Whether aware of it or not, whether seeking higher status or simply prevention from suffering public humiliation, the masses-across all classesparticipate in the growth of a consumer economy no longer able to generate happiness. ${ }^{[108]}$ And in the midst of humiliated lower classes, frustrated middle classes and self-conscious upper classes, these media strategies seem to be at least as powerful as the older tyrants, if not more: "In all [affluent] countries," Castoriadis adds, "they [the consumers] want them [the goods] because, while capitalism did not invent $a b$ ovo what is called the demonstration effect, it has raised it to a hitherto unknown degree of power." [100] Please ponder seriously on the fact that an average US child is exposed to 40,000 TV commercial a year, vicarious advertising.[111]

1.4 I have emphasised the non-naturalness of capitalism because it allows us to connect Castoriadis' work with McMurtry's and shed further light upon the axiological contradiction between democracy and capitalism. In the same passage quoted above, Castoriadis states: "For the moment, capitalism still manages somehow or other to deliver these goods. Here, the discussion can only stop: as long as people want this pile of junk, which is accumulating in a more and more haphazard way for a growing number of people, and with which they one day may or may not become saturated, the situation will not change." [112]

This passage and the remark about the hazardous junk in particular, allow us to reflect upon a fairly simple but most important matter: certain goods are "bads", in a way that the free market and the homines oeconomici do not often, if ever, grasp.[113] The "goods" that they want, produce, advertise, trade and exchange most profitably can be bad for the environment, bad for the many non-human life-forms inhabiting the same environment, bad for people's health-mental as well as physical-, bad for people's children and children's children, and bad for their hopes of self-rule and 
autonomy. In other words, the aims of capitalism are not those of biological, mental and political life, which, instead, democracy wishes to serve by granting people the ability to shape the free society in which to live so as to increase their chances to be content, if not even happy. This is the core of McMurtry's critical analysis of neoliberalism, at which, thus far, I have merely hinted.[114]

1.4.1 Analogous to Castoriadis' case, also McMurtry's one begins by addressing the work of Karl Marx. Specifically, it begins with Marx's outline of the regulating sequence of determination of the capitalist economy. This is a point of Marx's that neo-classical economists have retained to the present day. In his works, McMurtry refers to it as the "money-capital sequence", for monetary wealth is invested (input) in commodity production and/or stocks in order to command more monetary wealth (output)-the standard way in which economic activity is understood in today's academe, whereby monetary value is the thin, universal, uncontroversial and sole expression of value available to the scholar. ${ }_{1151}$ The formal expression of this sequence is the following:

$$
\$ \rightarrow C \rightarrow \$
$$

"\$" refers to the initial money input, "C" to the commodities or stocks in which the money input is invested (e.g. the automobile industry, agribusiness, or marketmargin speculation), and " $\$ \mathbf{1}$ " to the money output, which must be higher than the input, either by reduction of the input (e.g. cost abatement by downsizing or avoidance of labour and safety taxes) or by increase of the output (e.g. revenues increase by re-investment in short-term currency speculation or avoidance of capital gain taxes). The obligation to determine an output that is higher in monetary value than the original input derives from the "fiduciary duty" existing between the corporate subject and its stockholders, whose assets are expected to increase in value ad infinitum, unless the corporate subject ceases to exist.[117]

1.4.2 Against the money-capital sequence McMurtry sets the "life-capital sequence", as also ranges of biological movement (or action), felt being, and thought are invested in the production of means of life furthering broader and deeper ranges of biological movement, felt being, and thought.[118] Recycling industries, public management of community water aquifer, and universal education are examples of life-capital producing means of life producing more means of life in return-the way in which a life-value economy ought to operate.

Specifically, McMurtry's axiology states that " $X$ is value if and only if and to the extent that $x$ consists in or enables a more coherently inclusive range of thought/experience/action" and that such principle of value is:

(1) universalizable across all domains and issues of value judgement (ie., there is no domain of value to which it does not apply as the underlying principle of true value in all degrees of worth); (2) presupposed in value judgements and conflicts of all kinds (ie., each value perspective and conflict expresses this value ground, but only in limited aspects); (3) effectively a-priori (ie., to affirm its denial is nonsensical); (4) objective (ie., whatever qualifies in principle or fact is true value independent of its recognition by valuers); (5) sovereign or overriding in its relations to all other values (ie., in the case of 
any conflict of values, the position which most comprehensively embodies its principle is the more valid conception or position); and (6) a contingent pattern in long-term evolutionary and historical development (ie., the pattern of more inclusively enabled life fields obtains through planetary time, but may not in the future).[119]

The formal expression of the life-capital sequence is the following:

\title{
$\mathbf{L} \rightarrow \mathbf{M}$ of $\mathbf{L} \rightarrow \mathbf{L}^{1}$.
}

"L" refers to the initial input of life-capital invested in the means of sustenance and promotion ( $\mathbf{M}$ of $\mathbf{L}$ ) of wider ranges of life-capital to be obtained as an output ("L1"). As regards the calculation of this capital, McMurtry expands on the recent, alternative econometrics that have been developed by the United Nations and other institutions to deal with the dimensions of human capital and natural capital (e.g. HDI, GPI, the Statistics Canada System of Environmental and Resource Accounts). Specifically, McMurtry outlines a comprehensive "Well-Being Index" based on a basic minimum parametric of nine life means whereby to determine whether basic lifeneeds are being successfully addressed by a given socio-economic system and whether life-capacities are being enhanced further. The nine life means are:

\begin{abstract}
breathable air, sense-open space, and daily light (atmospheric means of life)... clean water, nourishing foods and self-waste disposal (bodily means of life)... shelter space from the elements with ample provision to retire, sleep and function (home means of life)... environmental surroundings whose elements and contours contribute to the whole (environmental means of life)... intimate love, social inclusion, safety and healthcare when ill or infirm (caring means of life)... activities of language-logos/art-play to choose and learn from (educational/recreational means of life)... meaningful work or service to perform (vocational means of life)... [and] self-governing choice in each's enjoyment consistent with each's provision (just form of life [121],
\end{abstract}

\section{i.e. genuine self-government or self-rule of the human communities. ${ }^{[122]}$}

1.4.3 As Jeff Noonan observed in a recent book, McMurtry's need-based approach brings to the fore a long history of actual demands by human societies, whose members have fought for wider access to and distribution of those means of life, typically controlled by and exploited for the benefit of the ruling oligarchy, including liberal ones. ${ }^{[123]}$ These struggles, which Castoriadis would describe as "emancipatory", have aimed typically at securing that which McMurtry calls "civil commons", i.e. "the organized, unified, and community-funded capacity of universally accessible resources of society to protect and to enable the lives of its members as an end in itself."

This notion should not be confused with Garrett Hardin's unregulated "commons", whose tragic doom justifies their appropriation for private ends. ${ }^{[125]}$ On the contrary, the appropriation of the commons for class or elite benefit and their conversion into means to non-universal and/or non-life-enabling ends has been resisted for centuries worldwide, from the English peasantry opposing $16^{\text {th }}$-century enclosures, to today's EU-wide protests against the Bolkenstein directive, through the Catholic-Communist Costa Rican social legislation of the 1940s-70s. Life-capital efficiency is the priority behind all these instances of popular action, which the neoclassical paradigm cannot 
but interpret as "bad for business", for the parameters of its own notion of efficiency are life-disconnected.

From an epistemological point of view, the ontological and axiological dimensions of life and life-needs have not been and cannot be computed by the Newtonian-physicsmodelled econometrics of either classical or neo-classical market theory, which deal with "uniform, invariant sequences" of "externally observable and quantifiable" objects. ${ }^{[126]}$ Life is blinkered out a priori by such standard systems of economic calculus, for it does not display the necessary features of the particular objects that can be handled by it, namely inanimate objects following unvarying patterns of behaviour. Indeed, the "ontocidal," automatic exclusion of these most fundamental dimensions of reality itself, which are the pre-condition for the existence of any market economy, explains why many institutions have proceeded to the creation of

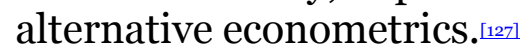

If, from a logical point of view, the disconnection of the money-capital from the lifecapital does not imply necessarily any conflict between them, the same disconnection does not imply mutual flourishing either. And insofar as autonomy (or freedom or democratic means of self-rule) is a means of life, then it does not possess any necessary connection with capitalism. In brief, the variable of life is simply alien to money-capital sequences. In practice, however, the conflict between the two capitals is ripe, to the point that McMurtry speaks of "value wars".[128]

1.4.4 Consistently with Castoriadis' own assessment, McMurtry observes how, in the last thirty years of worldwide "liberalisation", money-capital has been taken more and more often as the only structure of understanding directing any "rational" and "scientific" process of policy-making. In other words, neo-classical economics has become much more than a possible interpretation of certain economic phenomena: it has become the paradigm of human rationality itself and the basis upon which any form of human progress can be achieved, including political emancipation.[129] Throughout a combination of non sequitur statements, rhetorical rejection of alternative views, mass-media propaganda, culpable denial of historical evidence, and the eschatological (and non-falsifiable) assumption of a deistic "invisible hand" that will solve all problems, the "group-think" has locked many minds within a set of equations reading: "Global Corporate System $=$ Free Market $=$ Freedom $=$ Democracy $=$ Prosperity $=$ Development". ${ }^{[130]}$ Such a set of equations is hardly tenable before any serious intellectual scrutiny, but it can prove very effective if "no alternative" is allowed to exist $a b$ initio, for any alternative is bound to be, by definition of the paradigm, "irrational" and "unscientific".[1311

In other words, the underlying, unanalysed, de facto metaphysical stance of the world's leading institutions (with the IMF and the WTO in primis) has become a contractarian doctrine depicting a universe of self-maximising, informed, responsible, and free individuals, who trade material goods in the competitive market ${ }^{[132]}-$ all this being done and believed in spite of the facts, which speak of: interdependent, self- and all-minimising individuals (viz. ecocidal global warming, depletion of sources of fresh water, human-activity-related cancers, and losses of lifecapital in general) deprived of the information required to make rational choices (viz. WTO-dictated labelling prohibitions)[ณ33] who, for the largest part, are not 
trading at all (especially the unemployed masses that cannot trade their labour for wages, or the millions who have to accept precarious jobs since starvation is the only other alternative) ${ }^{[331}$ for it is corporate subjects, not individuals, that perform most of the world's trade (The largest 300 corporations, for example, control 98 per cent of all foreign direct investment, and 60 per cent of all land cultivated for export), ${ }^{[135]}$ with such trades being mainly virtual in nature (financial speculations count for at least three quarters of all commercial transactions since the beginning of the $20^{\text {th }}$ century, and regularly squeeze resources from the largest part of society in favour of the 1\% world's economic elite controlling the levers of financial power, as suggested by the prolonged paucity of GPI-measured growth in the industrialised country in the decades of liberalisation), ${ }_{136]}^{13}$ and such corporate subjects being neither fully liable (for corporations enjoy limited liability, as no other citizen does, both at the domestic and, in particular, at the transnational level), ${ }^{[137]}$ nor free (for corporate subjects are bound to their stockholders by fiduciary duty), ${ }^{[138]}$ nor involved in any competitive market (as what we have in fact is an oligopoly of corporate companies ${ }^{[390]}$ dictating the rules of the game unilaterally to bribed and/or financially dependent governments, , 140$]$ which enforce such rules onto their citizens i.e. by operating a continuous governmental interference in the market, in an endless pursuit of increased profits ).[141]

1.4.5 Evidence notwithstanding, most governments have followed the neoliberal commandments blindly, or, more appropriately, life-blindly. Whether they did so willingly or because under financial and/or military threat, they all re-shaped the very fabric of their communities-often with dramatic effects on the lives of the populations involved. The quest for maximised money-capital outputs does not stop before anything and can impair intellectual growth, health, or democracy, if such non-computable entities operate as "barriers to trade", or as life-enabling, but profitreducing "protectionism". Representatively, "Sub-Saharan African and East Asian countries like Indonesia and Pakistan now pay up... more for debt-servicing foreign banks or military-industrial providers than they do to public education and healthcare."[142]

McMurtry's research provides an incredible amount of additional evidence in this direction, as he also investigates the social and economic misfortunes of Argentina, Bolivia, Brazil, Canada, Colombia, Ecuador, Guatemala, India, Iraq, Japan, Korea, Mexico, Nicaragua, Russia and its former territories, Thailand, the former Yugoslavia, and the United States. Life-capital significant figures in job insecurity, lack of healthcare and education, depression, and suicide have all been increasing in these countries as a consequence of the compliance with the life-blind logic of moneycapital sequences-all these being losses that GDP figures cannot individuate by their very nature. $[143]$

Most tellingly, the language used by the governments involved in this global pattern of "rational" re-shaping of entire countries speaks of "restructuring" and "reengineering" societies through "necessary sacrifices" in order to "compete in the new global market," as if even the blindest subservience to the neoliberal paradigm could not completely hide the life-destructive implications of its application. Only the European Union, in McMurtry's view, has not succumbed entirely to the neo-classical 
"Stalinisation" of the world's economy, and is thus regarded as a model of more liferespectful development.[144]

1.4.6 The conceptual limitations of the neoliberal paradigm are most evident when we de-construct the four basic money sequences of money-capital, which are standardly confused.

$$
\text { (1) } \$ \rightarrow \mathrm{C}+\rightarrow \$^{1}
$$

$[\mathbf{C}+$ : to degree that $\mathrm{C}$ is life-enabling commodity with minimum or no life-destruction to people and/or to the environment by its production and/or consequences (e.g. organic foods production, self-powered vehicles)].

$$
\text { (2) } \$ \rightarrow \mathrm{C}-\rightarrow \text { \$1 }
$$

[C-: to degree that C- is non-life-enabling commodity with life-reduction to people and/or environment by its production and/or consequences (e.g. junk food, fueldriven recreational vehicles)].

\section{(3) $\$ \rightarrow$ DC $\rightarrow$ \$1}

[DC: a commodity constituted so as to reduce or to destroy life- organisation by its nature (e.g. armaments and cigarettes)].

\section{(4) $\$ \rightarrow \$^{1} \rightarrow \$^{n}$}

[Money is transformed into more money with no good or service produced in between (e.g. transnational currency speculation)].

Money Sequence (1) is benign, and to be selected for by the steering mechanisms provided by McMurtry's life-capital econometrics. Sequences (2) and (3) depict the material processes of the "Corporate Commodity Cycles," whose cumulative depredations of human and environmental life organisation are not factored into the market value calculus at any stage of their repertoires of eco-dismantling, extraction, processing, transportation, packaging, advertising, consumption, and non-recovered disposal.[145] (4) represents the extreme case of utterly life-detached economy, as it does not even deal with material goods, but only with virtual ones, by means of which, however, it can command over all other operations of the Corporate Commodity Cycles. Financial speculation, private money-creation by inflated assets, and unregulated credit generation are the unseen, inflationary pumps of the debitridden, merger-obsessed corporate juggernaut dictating the path of globalisation. ${ }^{[146]}$

1.4.7 The unifying economic principle of all steps of this process is one alone, however, namely externalisation of the costs of for-profit commodity cycles onto those who do not profit from them. ${ }^{147]}$ Moreover, ecological degradation may be selected for pro-actively, inasmuch as increased scarcity of vital goods may augment 
their profitability as priced commodities. Given the life-blind conceptual parameters of the neoliberal paradigm, vast-scale life-threatening activities can be seen as desirable qua business opportunities and consistently pursued (e.g. highly-polluting mining and shipping opportunities for profit due to global warming in the Arctic region). ${ }_{[148]}$

According to McMurtry, in order to counter-balance the harmful pattern of unrestrained self-replication of capital money sequences [especially of the type (4)], his Value Wars proposes a "life-value turn". If and only if the way we look at the universe is informed by life-centred preoccupations, the defence of human and environmental life organisation can be achieved. As Sorel and Pareto often remarked in their works, any political-economic system, no matter how "progressive", "just", or "free", can and will be corrupted eventually by its members, if a significant part of them lack personal integrity. Analogously, Marcuse used to teach that before consumer society is liberated by its members, its members must liberate themselves from consumer society, i.e. they must undergo a process of thorough revision of their innermost beliefs and deep-seated attitudes.

On an institutional level, this life-value turn translates, amongst other things, into systematic accountability procedures of:

(A) Corporate internalisation rather than externalisation of costs; and

(B) Regulatory reduction or prevention of life harms by the Corporate Commodity Cycles.

For example, obligations to comply with life-protective regulations can be instituted as binding articles of international trade and access to other societies' markets. Trade sanctions are continuously enforced on a global scale. Modern computer technologies allow for instantaneous cross-checking of all major transactions. Hence, as McMurtry suggests, the same ought to be done with regard to the assessment of new types of sanctions to be introduced, these being directed to the fulfilment of life-protecting and life-promoting ends. Besides, McMurtry's life-value turn implies restoring national and international legal sovereignty over corporate fictitious persons, "who", for instance, are recognised human rights in their defence (the right to hold private property in particular), but against "whom" no legally valid accusation of violation of human rights can be formulated (for only State agents in the exercise of official duties can be charged with human rights violations). Similarly, legal responsibility must be re-instituted by removing limited liability privileges, which allow investors to ignore whether they finance private companies involved in murderous or ecocidal activities. $[140]$

2.o It may be wondered whether the shift of existing capitalism towards a life-value economy is affordable. Probably, the few points presented hereby make it look like a disincentive to entrepreneurial activity. Yet, if life-centred preoccupations are to be taken seriously, then McMurtry's work allows us the following four considerations, which may reassure the more business-minded audience:

(a) It is the current systematic destruction of life-capital by the 
unaccountable externalities of corporate money-capital that is disastrously unaffordable;

(b) Life-protective standards can be enforced through trade agreements as cost-effectively as protection of private patents and other corporate rights are by incentives/penalties of trade access/tariff or fines; moreover, most of them are already in place, although they are regularly unimplemented and their supervising offices under-funded or otherwise impeded from performing their task;

(c) The current competitive advantage of externalising vast costs onto those who cannot afford them, and the cost-penalisation of responsible corporations, are simultaneously removed by a level playing field of market competition regulated by life standards;

(d) The macro recessionary/depressionary trend of world economies requires a major demand stimulus of life-capital protection and formation to ensure the health and security of global citizens in place of the spectacularly wasteful and destructive public investments in and subsidies for military commodities and industrial agriculture.

History will tell whether these considerations will become part of ordinary business life or not. On my part, I dread to think of a planetary future in which none of them has been turned into standard practice.[50]

[1] It is always difficult to decide what to present in the main text and what in the endnotes. I opted for a slender main text and a lengthy critical apparatus in the footnotes in order to facilitate the reading of this essay, yet without sacrificing entirely the need for depth and substantiation of the points made in the former. Taken per se, Castoriadis' considerations about the origins of capitalism and its axiological departure from autonomy and democracy are rather commonplace in socio-historical and philosophical literature. However, when projected against the backdrop provided in the footnotes, they display the remarkable insightfulness and complexity of Castoriadis' work.

[2] Adam Smith had already used the term "free trade" to describe what we have come to know as "capitalism".

[3] All of these terms have been defined and used in many different ways through the centuries; hence, with the exception of "neoliberalism", I shall rely upon Castoriadis' understanding of them in order to reduce the room for ambiguity. I write "reduce" and not "eliminate" for ambiguity is de facto unavoidable when dealing with abstract political terms. Indeed, to eliminate all ambiguity by means of definitional stipulations would probably generate terms that cannot be expended in the arena of social and political science. This is particularly true vis-à-vis "democracy", which has had such a varied history. Moreover, Castoriadis himself variously conflates, connects and distinguishes "democracy", "autonomy" and "freedom", hence I cannot but reflect the semantic licences that he allowed himself to take.

[4] Famously, Juergen Habermas has described this process as the "unfinished project" of modernity.

[5] Bill Clinton, Between Hope and History, New York: Random House, 1996, p. 36. I have chosen a quote by a political world leader from the left-wing camp (i.e. as far left as any politician can be whilst reasonably aspiring to the presidency in the USA), for neoliberal policies are commonly associated with right-wing parties and politicians-probably due to the 1970s-80s examples of Margaret Thatcher and Ronald Reagan-but in effect became much more widespread in the 1990 os across the whole political spectrum, to the point of forming eventually the "common wisdom" of most $21^{\text {st }}$-century decision-makers and world leaders, particularly in Europe and North America. 
[6] I have addressed briefly post-communist Russia's unprecedented depopulation, decrease of life expectancy, proliferating ethnic wars, and reversal to despotism as negative signs in my essay "The Life-Ground of Sustainable Development. Reflections on Ecology, Social Sciences and Politics in Honour of Sergi Avaliani", in Irakli Kalandia et al. (eds.), Problems of Classical and Contemporary Philosophy. Sergi Avaliani - 8o, Tbilisi: Universal, 2008, pp. 142-75. The following text is also recommended: B. Anderson, "Russia Faces Depopulation? Dynamics of Population Decline", Population and Environment, 23(5), 2002, pp. 437-64.

[7] To this end, I shall make use also of writings by McMurtry yet to be published or existing currently in manuscript form only. I wish to thank Professor John McMurtry for courteously allowing the publication of quotes and excerpts from unpublished material.

[8] In this perspective, I must warn the reader that Castoriadis' historical and axiological awareness moves in parallel and is often revealed in passages where the shift in value-orientation is observed as the history of the transition from non-capitalist to capitalist societies.

[9] Whereas I cannot boast any significant expertise vis-à-vis Castoriadis' work, I can claim it as regards McMurtry's, with whom I have collaborated for almost ten years, initially as a PhD student of his and then as a colleague.

[10] Redundant may seem also to be interested in criticising the neoliberal paradigm, since its shaky theoretical foundations, its contradictory historical record, and its current ecocidal effects have been unmasked and criticised before. However, its resilience and its ability to influence the ruling class and vast sectors of the population of many countries suggest that further forceful critical efforts may be needed.

[11] The Nordic Summer University website, http://www.nsuweb.net/wb/, last accessed on Wednesday, 28 November 2007.

${ }^{[12]}$ See also my contribution to the fifth volume of the Death and Anti-Death series, edited by Charles Tandy and yet to be published by Ria Press.

[13] Democratic regimes, including communistic ones, appeared not solely in the urban centres of the Hellenic peninsula, but also in rural and colonial settlements in Southern Italy and the Black Sea region [see Pia Guldager Bilde and Vladimir F. Stolba, eds., Surveying the Greek Chora. The Black Sea Region in a Comparative Perspective. (Aarhus: Aarhus University Press, Black Sea Studies 4, 2006)]. [14] Castoriadis locates the end of the Middle Ages between the tenth and eleventh century, which witnessed the formation of strong, de facto if not de iure independent communes, cantons and municipalities, in opposition to the enduring cosmopolitan structures of the Church and of the Empire. Only one such medieval democracy has survived to the present day: the Confederation of Helvetia or Switzerland.

${ }^{[15]}$ Historical research suggests that risk-averse family farmers were behind democratic and republican regimes in ancient Greece and Italy, rather than protobourgeois merchants, as in Medieval Europe (see A. W. Griswold, Farming and Democracy, New Haven: Yale University Press, 1948 and V. D. Hanson, The Other Greeks: The Family Farm and the Agrarian Roots of Western Civilization, New York: The Free Press, 1995).

[16] Cornelius Castoriadis, "First Institution of Society and Second-Order Institutions", in Figures of the Thinkable. Including Passion and Knowledge, translated from the French and edited anonymously as a public service, downloaded from www.notbored.org, last accessed on Monday, 26 November 2007, p. 162. The translator and editor of this volume and of The Rising Tide of Insignificancy saw himself compelled to release anonymously and for free these extensive collections of recent writings by Castoriadis (mainly from the late 1980s through the 1990s) because of an ongoing legal battle for publication rights involving, amongst others, Castoriadis' family and Stanford University Press. In this paper, I make use these two volumes because of scholarly and practical reasons. First of all I value their lateness and comprehensive character, since they allow for a precious and extensive presentation of Castoriadis's views in his maturity. Secondly, these volumes' consistent, thought-through English prose is the fruit of one man's work. Thirdly, their being accessible online simplifies my search for works by Castoriadis to be used while preparing this essay, which I did across three different European countries.

[17] Cornelius Castoriadis, "Imaginary and Imagination at the Crossroads", Figures of the Thinkable. Including Passion and Knowledge, p. 129. The notion of "significations" is particularly important, for it shows how the sought-after liberty goes beyond the sphere of legal-constitutional affairs, reaching that of existential-spiritual affairs, as the citizenry are recognised the freedom to revise cherished 
traditions, beliefs and values in their pursuit of a meaningful existence. In this perspective, it combines with the Marxist notion of "alienation" (i.e. infra alia, "deprivation", "theft", "removal", "estrangement", "loss"), which Castoriadis also employs in his works, and which addresses at least four types of loss suffered by the waged labourer because of the profit-driven interests of the employer: of the product (i.e. the final artefact does not belong to those who made it and often those who made it cannot even afford to buy it); of the production (i.e. individual, unique, creative craftsmanship and mastery are replaced by cost-effective, mechanised, routinised activities); of individuality (i.e. workers perform so cost-effective, mechanised, routinised activities, that a host of other persons can do them nearly identically, whether younger, older, female or male; workers become easily replaceable and extremely vulnerable to competition on the labour market, hence their individual bargaining power is reduced and their cost to the employer, as a result, is also reduced); of humanity (i.e. workers perform so cost-effective, mechanised, routinised activities, that hardly anything distinctively human is required of the worker; sometimes machines can replace the worker altogether; other times the only way to work is by adjusting unnaturally one's human skills, whether physical or intellectual, to the machine; new work-related pathologies emerge; the intensity, duration and/or conditions on the workplace are so tiring and/or stressful that the worker's free time is left to the satisfaction of the worker's animal needs, rather than to the cultivation of more distinctively human faculties)

[18] Id. To be honest, whether justifiably or not, in today's allegedly democratic countries the freedom to call into question existing institutions and significations is limited in various ways, including the rather immaterial and basic level of freedom of speech. Far from being free to utter, write and distribute whatever she thinks, today's democratic citizen must deal with: a host of libel and defamation laws; prosecution of hate speech, blasphemy and "negationist" stances; censorship of violent, pornographic, unpatriotic or other "dubious" utterances and texts; not to mention copyright protection of songs, slogans and other sub-sections of ordinary as well as technical languages. In comparison, the citizen of the Roman republic at the time of Cicero enjoyed a much broader freedom of speech.

[19] Although eventually dissolved within the feudal forms of institutional organisation exemplified and imposed by the powerful, centralised crowns of Spain, France, England and Augsburg Austria, medieval republics and "free cities" often displayed economic dynamics analogous to capitalist ones, particularly in wealthy commercial and financial centres like Florence, Genoa, Venice, Bruges and Antwerp. Similar economic developments, though less frequently associated with democratic experiments, were also visible in several Islamic merchant towns around the Mediterranean Sea of the Middle Ages. Despite the general neglect for these early and relatively unsuccessful capitalist experiments in English- and German-speaking historiography, many technical and institutional elements of the Atlantic-centred capitalism studied by Weber et alia were forged in such realities (e.g. stock creation and exchange, cheques, promissory notes).

[20] Cornelius Castoriadis, "The 'Rationality' of Capitalism", Figures of the Thinkable. Including Passion and Knowledge, p. 87; emphasis mine.

[21] Cornelius Castoriadis, "Third World, Third Worldism, Democracy", The Rising Tide of Insignificancy (The Big Sleep), translated from the French and edited anonymously as a public service, downloaded from www.notbored.org, last accessed on Wednesday, 12 December 2007, p. 53.

[22] Cornelius Castoriadis, "Imaginary and Imagination at the Crossroads", Op. cit., p. 129. The hypothetical datum at issue is very hypothetical and historically most dubious (see following note), yet it has become part of the public mindset, analogously to the way in which the saintliness of the first Christian Emperor Constantine was a widespread yet utterly false belief upheld by Christians until the $18^{\text {th }}$ century.

[23] The perplexing twinning of capitalism and democracy blossomed in the 1990s while several serious historians were reminding us of the substantial survival of capitalist economy under fascist and military dictatorships, e.g. Mussolini's Italy, Hitler's Germany, Pinochet's Chile (see Eric Hobsbawm, Age of Extremes: The Short Twentieth Century: 1914-1991, London: Michael Joseph, 1994/Abacus, 1995).

[24] Cornelius Castoriadis, "Democracy as Procedure, Democracy as Regime", The Rising Tide of Insignificancy (The Big Sleep), p. 350.

[25] Cornelius Castoriadis, "The Dilapidation of the West", The Rising Tide of Insignificancy (The Big Sleep), p. 88.

[26] To take seriously the historical eventuality of economic reality means to be less prone to regard 
economics as the abstract study of properties, relations and combinations of select theoretical entities, analogous to physics and, more à propos, $19^{\text {th }}$-century mechanical engineering, i.e. the discipline upon which modern economics was modelled by Ricardo and others. It means also to look more carefully into the individuals and the individual circumstances that determine economic life, i.e. to operate inductively and ideographically, rather than to develop law-like abstract models of economic life, perhaps to be applied successively and politically to real-life communities, i.e. to operate deductively and nomothetically. However, as a broader epistemological point, the historical eventuality of capitalism highlighted by Adam Smith implies a reduction of its scientific necessity, i.e. that it was inevitable for capitalism to come about. Indeed, by linking this (or any other) economic system to the chances and circumstances of human affairs the room for any scientific claim of "naturalness" is reduced, whether physical, biological, anthropological or sociological. Since there is no other world, no other humankind or history constituting a "test group" to compare it with, one may aspire only to convincing generalisations or explanatory hypotheses based upon unrepeatable happenings.

[27] Adam Smith, An Inquiry into the Nature and Causes of the Wealth of Nations, "Of the Rent of Land", I.11.163-4.

[28] Ironically, the neoliberal aspiration to discover the natural laws determining historical and economic affairs and to link these laws with the necessary, unavoidable realisation of a propitious political system is something that they share with their sworn enemies, i.e. revolutionary Marxists.

[29] Lafayette was no Marat, Mill was no Owen, and Cavour was neither Mazzini nor Garibaldi: the great divide between liberals and republicans seems forgotten in today's ordinary treatment of the history of democracy, as though universal suffrage and unhindered equality before the law were an obvious step in the history of liberalism. Yet this step was hardly obvious to the "radical" men and women that, from the days of the American Revolution to the granting of the right to vote for federal elections to all Swiss women in the 1970s, fought hard and long to be allowed to take it. A commendable exception to this oblivion is Jeff Noonan's recent study Democratic Society and Human Needs (Montreal: McGill-Queen's University Press, 2006), where the differences and the conflicts between the liberal and the republican movements in the late $18^{\text {th }}$ century and throughout the $19^{\text {th }}$ century are outlined most clearly and analysed as orbiting around a struggle between the centrality of rights (especially property rights) versus life needs.

[30] Adam Smith, Op. cit., "Of the Rent of Land", I.11.261-3.

[31] Id.

[32] Ibid., "Of the Wages of Labour", I.8.38.

[33] Ibid., "Of the Rent of Land", I.11.263.

[34] Adam Smith's famous "invisible hand" is not a metaphor, but God's Providential plan in acto, for the individual pursuing "only his own gain" is truly "led by an invisible hand to promote an end which was no part of his intention" (Ibid., "Of Restraints upon the Importation from Foreign Countries of such Goods as can be Produced at Home", IV.2.9). Here lies the forgotten superstitious assumption of classical as well as neoclassical economics.

[35] Ibid., "Of the Rent of Land", I.11.263.

[36] Ibid., "Of the Expence of Justice", V.1.55.

[37] In my essay "Cesare Beccaria and the Cruelty of Liberalism" (Philosophy and Social Criticism, 30/o3, pp. 303-13) I discuss an analogous, interesting case of liberal bluntness vis-à-vis the intrinsic cruelty of private property, which causes pauperism, hence theft, hence the intervention of penal justice, which Beccaria characterises as intrinsically cruel, and yet accepts as part of a desirable social system.

[38] Cornelius Castoriadis, "The 'Rationality' of Capitalism", Op. cit., p. 88.

[39] An interesting exception to this trend was constituted by Vilfredo Pareto, who was not only a staunch liberal, but also one of the decisive figures in the history of economics vis-à-vis the formalisation and mathematical symbolisation of this discipline. Although he never abandoned the idea that mathematical economics could give us some rough yet useful general picture of economic life, he did realise in his maturity that the tools of economics, even when cast in as "scientific" terms as possible, fell short of comprehending and explaining human behaviour, both individual and collective. Too complex, unpredictable and irrational, human behaviour needed additional and alternative means of comprehension and explanation, which Pareto endeavoured to provide in his monumental 1916 Trattato di sociologia generale (translated in 1935 into English as The Mind and Society). Belated and yet little aware of the intrinsic limitations of neoclassical economics comes the late-20 ${ }^{\text {th }}$-century study 
of market "irrationality", which sneeringly assumes that human beings who do not operate according to the principles posited by classical and neoclassical economists are not rational.

[40] Cornelius Castoriadis, "The 'Rationality' of Capitalism", Op. cit., pp. 87-8.

[41] I have tackled in finer detail the issue of the abstractedness of modern science in my essay "Galileo's Animale and Heidegger's Gestell: Reflections on the Lifelessness of Modern Science" (Charles Tandy, ed., Death and Anti-Death Volume 4: Twenty Years After De Beauvoir, Thirty Years After Heidegger, Palo Alto: Ria University Press, pp. 29-66) and of economics in particular in my essay "Deadly Economics: Reflections on the Neoclassical Paradigm" (Charles Tandy, ed., Death and Anti-Death Volume 5, Palo Alto: Ria University Press, forthcoming). Also, I have reviewed for The European Legacy a recent celebratory republication of a classic text by one of the few economists that, during the $2 \mathrm{O}^{\text {th }}$ century, recovered and gave full consideration to the historical-geographical and wider socio-cultural aspects of economic phenomena: John Kenneth Galbraith, The New Industrial State, with a new foreword by James K. Galbraith, Princeton and Oxford: Princeton University Press, 2007.

[42] Cornelius Castoriadis, "The 'Rationality' of Capitalism", Op. cit., p. 91. This essay by Castoriadis contains an interesting critique of the utter abstractedness and flawed "scientificity" of modern economics.

[43] Not only did Marx aspire to establishing a society in which all citizens were free from despotic control, whether due to de iure legal-political oligarchic rule or by de facto oligarchic control of the available means of life; but also a society in which each citizen would be free to explore and cultivate her inclinations, interests and abilities. In other words, Marx's liberation from alienation comprises a horizontal component or breadth (i.e. freedom is to be distributed to all citizens equally, e.g. by liberating labourers from wage slavery) and a vertical one or depth (i.e. each citizen must be free to intensify her enjoyment of life, e.g. by being given free time and recreational opportunities). In this perspective, as later noted by Oscar Wilde in "The Soul of Man under Socialism", the realisation of socialism would have been the precondition for the actual realisation of liberalism, as each and every individual would have had then and then only a real chance to lead a meaningful existence, not just those few who, under a regime of private ownership, could afford it.

[44] Cornelius Castoriadis, "Imaginary and Imagination at the Crossroads", Op. cit., p. 129.

[45] Marx's criticism of private property did not mean to do away with all forms of private property, but rather to control and limit it so as to serve human life without distinction of class: "Capital is a collective product, and only by the united action of many members, nay, in the last resort, only by the united action of all members of society, can it be set in motion... We by no means intend to abolish [the] personal appropriation of the products of labor, an appropriation that is made for the maintenance and reproduction of human life, and that leaves no surplus wherewith to command the labor of others. All that we want to do away with is the miserable character of this appropriation, under which the laborer lives merely to increase capital, and is allowed to live only in so far as the interest of the ruling class requires it." (Karl Marx and Friedrich Engels, The Communist Manifesto, London: Penguin Classics, 1998, chapter II).

[46] In truth, it would probably bring us back to Soviet Russia, which Castoriadis criticised as "total and totalitarian bureaucratic capitalism" [Cornelius Castoriadis, "The Rising Tide of Insignificancy", The Rising Tide of Insignificancy (The Big Sleep), p. 125].

[47] Cornelius Castoriadis, "The 'Rationality' of Capitalism", Op. cit., p. 89.

[48] Ibid., p. 91.

[49] Ibid., p. 89.

[50] Ibid., pp. 89-90.

[51] There exists a "Darwinian" ethos in sectors of the business world, especially high-level finance, which self-fulfils the idea that the business community is "a jungle" of "throat-cutting" and "backstabbing" "money-grabbers" engaged in endless "competition", hence unavoidably "cruel", impermeable to "pie-in-the-sky", "bleeding-heart", "utopian" humaneness, and requiring "opportunism", "cynicism", "toughness" and "having-balls" qua "necessary evils" or "realism". Any restraint or improvement of this sorry scheme of things is seen as hopeless a priori. In yet another example of human self-alienation (further discussed in 1.3.1), the cynical cause the world to be a hell and then say that they are cynics because the world is hell.

[52] John McMurtry, "The Naturalistic Fallacy. Reflections on Evolutionary Theory as a Value System", in Irakli Kalandia et al. (eds.), Op. cit., p. 177.

[5.53] Id. 
[54] Ibid., p. 178.

[55] Id. The full development of the pathological model vis-à-vis contemporary global economy is given in John McMurtry, The Cancer Stage of Capitalism, London: Pluto Press, 1999.

[56] Cornelius Castoriadis, "The 'Rationality' of Capitalism", Op. cit., p. 91.

[57] Ibid., p. 92.

[58] Adam Smith and the neoliberal paradigm assume self-maximisation to be an anthropological datum, whence their understanding of human reality logically spreads out.

[59] Cornelius Castoriadis, "The 'Rationality' of Capitalism", Op. cit., p. 92.

[60] Cornelius Castoriadis, "Unending Interrogation", The Rising Tide of Insignificancy (The Big Sleep), p. 274.

[61] I believe the term "imperialism" is most appropriate here, for it derives from the Latin imperium, i.e. rule or mastery, and ties in with Castoriadis' following remark on omnipotence, i.e. the desire for absolute rule or mastery, both horizontal and vertical, namely over all potential subjects and all levels at which these subjects can be dominated. Moreover, as the opening quote in 1.2.2 shows, the notion of "mastery" is also used by Castoriadis himself.

[62] In the Western canon, there has been no paucity of alternative understandings of rationality and applications thereof to social, political and economic matters: Plato's, Aristotle's, Epicurus', Marcus Aurelius', Boethius', Aquinas', Pascal's, etc.

[63] In this sentence I am using the term "rationalisation" in a Freudian, rather than Weberian, sense, in order to facilitate a transition from Weber's empire of calculability to Castoriadis' remark on the hidden human craving for omnipotence.

[64] Cornelius Castoriadis, "The 'Rationality' of Capitalism", Op. cit., p. 93. In this perspective, 20 $0^{\text {th }}$ century "totalitarianism is only the most extreme point of... the demented capitalist project of an unlimited expansion of pseudorational pseudomastery... which, moreover, is inverted into its own contradiction, since in it even the restrained, instrumental rationality of classical capitalism becomes irrationality and absurdity, as Stalinism and Nazism have shown." (Cornelius Castoriadis, "The Rising Tide of Insignificancy" Op. cit., p. 135).

[65] Similar points about the birth and development of religion were made later by Nietzsche and Freud.

[66] John McMurtry, "Understanding Market Theology", paper presented at the Ninth International Conference on Studies in Economic Ethics and Philosophy, "The Invisible Hand and the Common Good", Trent University, Canada, June 13-16, 2002, p. 6

[67] Technically, formalised and symbolised neoclassical economics depicts this empirically-never-given yet theoretically-always-posited condition as equations of equilibrium of supply and demand.

[68] John McMurtry, "Understanding Market Theology", p. 4.

[69] Cornelius Castoriadis, "The 'Rationality' of Capitalism", Op. cit., p. 93.

[70] Id.

[71] Another term describing the same tendency of free-rein capitalism would be "totalitarian", as Hannah Arendt recognised towards the end of the last edition of her monumental Origins of Totalitarianism.

[72] As exemplified by John Rawls' notion of the democratic State's abstention from enforcing any positive notion of the good

[73] By means of psychoanalytical analogy, Gilles Deleuze and Félix Guattari have famously described capitalism as an "anal Oedipus" engaged in the hopeless destruction of the original chaos whence he himself comes from, i.e. his father (hence the oedipal character of capitalism), by relentless subjugation of every aspect of human reality (hence the anal character of capitalism), which cannot but fail, for reality is far too complex, diverse and unpredictable to be mastered once and for all (hence the hopeless, neurotic and pathological character of capitalism).

[74] John McMurtry, "Understanding Market Theology", p. 23. If, according to Weber's Protestant Ethics and the Spirit of Capitalism, it was once typical that the Catholic Church that seemed prone to "punishing the heretic, but indulgent to the sinner", the same is true now of the free market, which accepts corruption (e.g. German enterprises declaring bribes qua legitimate expenses deductible for income tax purposes) and mendacity (e.g. "expected" untruthfulness of companies' bookkeeping), as long as they do not disturb profit opportunities, and even praises immoral self-aggrandisement as opportunism, but aims at marginalising or destroying all "radicals" who may speak or act against it. [75] It is fairly ironical to observe the wave of proclaimed anti-statehood coming from the neoliberal 
camp, since no capitalist economy has developed in history without the presence and support of a powerful, articulate, far- and deep-reaching State.

[76] Cornelius Castoriadis, "The 'Rationality' of Capitalism", Op. cit., p. 93-5.

[77] Ibid., p. 96. Edmund Burke, though close to the classical school, recognised that "Even commerce, and trade, and manufacture, the gods of our economical politicians, are themselves perhaps but creatures; are themselves but effects, which as first causes, we choose to worship... They too may decay with their natural protecting principles." (Edmund Burke, Reflections on the French Revolution, London: Everyman's library, 1953, § 134). Burke referred to the venerable cultural, moral and religious traditions inherited from centuries of British history as the "natural protecting principles" of "the gods of our economical politicians", many of which were in fact not the result of prolonged adaptation to the environmental conditions of the country and successful provision to the ends of the population, but rather of prolonged oppression and exploitation by the British nobility. Still, some of them were so and most notably the Poor Laws, significantly abolished by the free-market Liberals in 1834 .

[78] Ibid., §§ 128 and 126.

[79] Cornelius Castoriadis, "The 'Rationality' of Capitalism", Op. cit., p. 96.

[80] $I d$.

[81] Cornelius Castoriadis, "Third World, Third Worldism, Democracy", Op. cit., p. 48.

[82] Ibid., p. 52.

[83] Cornelius Castoriadis, "The 'Rationality' of Capitalism", Op. cit., p. 96. In my native country, this resistance meant Mussolini's fascist regime.

[84] Minorities have often been the majority of a country's population.

[85] The liberal bourgeoisie even formed alliances with the former aristocratic rulers aimed at preventing further enlargement of the legal-political franchise (see for example J. A. Mayer, The Persistence of the Old Regime, New York: Pantheon Books, 1981). Typically, what all the excluded groups fighting for recognition had in common was not to own significant shares of the available property-the aristocratic anarchist Kropotkin was in this sense the exception, not the rule.

[86] Cornelius Castoriadis, "Anthropology, Philosophy, Politics", The Rising Tide of Insignificancy (The Big Sleep), p. 205; emphasis mine wishing to highlight Castoriadis' terminological continuity with Pareto.

[87] Cornelius Castoriadis, "The Dilapidation of the West", Op. cit., p. 79.

[88] In the $19^{\text {th }}$ century, the liberal Camillo Cavour was deeply aware of the different types and degrees of democratic rule available: "'Democracy' is a very elastic notion that can be equally applied to very different systems, and that corresponds to thoroughly distinct ideas when pronounced by Gioberti or Mazzini, Louis Blanc or some American belonging to the school of Washington or Jefferson" (Camillo Cavour, book review of History of Piedmont: Carlo Alberto's Kingdom by Angelo Brofferio, Il Risorgimento, III, 797, 27 July 1850, pp. 3-4).

[89] Immanuel Kant, Groundwork of the Metaphysics of Morals, translated and edited by Mary Gregor, New York: Cambridge University Press, 1998, pp. 42-3.

[90] Cornelius Castoriadis, "The Rising Tide of Insignificancy", Op. cit., p. 149.

[911 Cornelius Castoriadis, "Third World, Third Worldism, Democracy", Op. cit., pp. 51-2. George W. Bush and the "liberators" of Iraq seem not to have pondered upon this possibility.

[92] Sometimes, even the main supporters and actors of the neoliberal paradigm in recent times, namely the financial sector, may call for State intervention and regulation of the financial sector itself, as with the wave of panic following the 2007 liberalisation-ignited sub-prime mortgage crisis.

[93] Cornelius Castoriadis, "The Dilapidation of the West", Op. cit., pp. 87-8. Analogous considerations have emerged amongst the commentators of the so-called "Smith problem" i.e. the uneasy relationship between the benevolent and moral human being of Smith's Theory of Sentiment and the selfish and amoral one of Smith's Wealth of Nations (see José Atilano Pena López and José Manuel Sánchez Santos, "El problema de Smith y la relación entre moral y economía", Isegoría. Revista de Filosofía Moral y Política, N. ${ }^{\circ}$ 36, enero-junio, 2007, pp. 81-103).

[94] Id. and, infra alia, "The 'Rationality' of Capitalism", Op. cit., p. 96.

[95] The Mafioso, bullying others into submission, smashing competitors, and destroying lives for the sake of personal aggrandisement (hence the chilling phrase "it is nothing personal, it is just business"), exemplifies unnoticed the "successful" anthropological type that neoliberalism implies. Moreover, if one combines together the share of the world's wealth owned by financial speculators, self-serving top managers, and outright criminals, one is likely to realise that the "pirate" controls an enormous 
amount of monetary value.

[96] Cornelius Castoriadis, "The ‘Rationality’ of Capitalism", Op. cit., p. 90.

[97] $I d$.

[98] Id.

[99] Famous French medievalist Jacques LeGoff argued that the notion of Purgatory developed around the eleventh century to serve the needs of a bourgeoning Christian merchant class caught between the pursuit of earthly wealth and the aspiration to a divine Heaven forbidden to the rich person by admonition of Jesus Christ himself.

[100] Contemporary female rhythm \& blues band called Pussycat Dolls sings: "The best things in life are free / But you can keep'em for the birds and bees / Money / That's what I want..."; twenty years earlier Madonna extolled the "virtues" of the "material girl"; one can even step back to Marilyn Monroe's claim that "diamonds are a girl's best friend": since the inception of post-war consumerist capitalism, there has been no paucity of popular expressions of the anthropological model endorsed by neoliberalism, which medieval Christian theologians as well as the "diabolic" Machiavelli would describe as expressions of avarice or greed. I emphasise how these expressions may place love in a subordinate position, for love has been traditionally the highest value praised by popular singers, whether medieval minstrels, baroque stage actors, Romantic sopranos or Victorian actresses.

[101] Cornelius Castoriadis, "The 'Rationality' of Capitalism", Op. cit., p. 115.

[102] See Jeremy Rifkin, The Age of Access: the New Culture of Hypercapitalism Where All of Life Is a Paid-for Experience, New York: Tarcher/putnam, 2000.

[103] Praising fashion designer Giorgio Armani, Amy M. Spindler displays how unnatural this process is: "selling fashion means creating new needs, and most men do not need another classic jacket. Armani is an expert at creating new needs" ("Review/Fashion; In Milan, Bold Visions And a Softer Silhouette", 1 July 1993, retrieved on www.nytimes.com, 22 May 2007; emphasis mine).

[104] As Benjamin Barber discusses in his recent book Consumed: How Markets Corrupt Children, Infantilize Adults, and Swallow Citizens Whole (New York: Norton, 2007), basic impulses, not selfcritical thinking, are fostered by market strategists since early childhood-and the adult human being needed for democratic life is very different from the eternally adolescent shopper fostered by capitalism, at least in its consumerist guise.

[105] John K. Galbraith, The New Industrial State, with a new foreword by James K. Galbraith, Princeton and Oxford: Princeton University Press, 2007, p. 144.

[106] See Jean Baudrillard, La Société de consummation, Paris: Éditions Denoël, 1970.

[107] See Thorstein Veblen, Theory of the Leisure Class: An Economic Study in the Evolution of Institutions, London: Penguin, 1994.

[108] See Bruno Frey and Alois Stutzer, Happiness and Economics, Princeton: Princeton University Press, 2002; and Joseph Heath and Andrew Potter, The Rebel Sell. How the Counterculture Became Consumer Culture, Southern Gate Chichester: Capstone, 2005.

[109] Cornelius Castoriadis, "The 'Rationality' of Capitalism", Op. cit., p. 115. To the "demonstration effect" due to brainwashing, one should add the active destruction of non-capitalist economies and forms of social life by diverse means, including the threat or use of military force and large-scale financial usury. Moreover, one should consider Castoraidis' awareness qua psychotherapist of the tremendous amount of pain that this system imposes upon the "losers" who cannot afford and/or achieve the material symbols of success and/or are pushed to the margins of the "free" society because unwilling and/or unable to conform. Naturally, mechanisms for social exclusion have always existed, and very painful ones too, but never before the age of television was the propagation of the dominant mindset so pervasive and uninterrupted.

[110] As regards the role of television in less affluent countries, Castoriadis remarks: "Televisions, too, rank among these gifts [from Europe]... allowing... [the] sergeant... [that] seize[s] power and proclaim[s] a socialist people's revolution while massacring a fair proportion of his compatriots... to go about stupefying the population." (Cornelius Castoriadis, "Third World, Third Worldism, Democracy", Op. cit., p. 51). Although Castoriadis does not assert that "televisual" propaganda annihilates critical thought and free will, he endorses the notion that it does bamboozle its target audience to a noticeable extent.

[111] Eric Clark, The Real Toy Story: Inside the Ruthless Battle for America's Youngest Consumers, New York: Free Press, 2007. On advertising, Castoriadis observes: "The atomization of individuals is not autonomy. When an individual buys a fridge or a car, he does what forty million other \{French\} 
individuals do; there is here neither individuality nor autonomy. This is, as a matter of fact, one of the mystifications of contemporary advertising: 'Personalize yourself, buy Brand X laundry detergent.' And millions of individuals go out and 'personalize' (!) themselves by buying the same detergent." (Cornelius Castoriadis, "The Rising Tide of Insignificancy" Op. cit., pp. 148-9).

[112] Cornelius Castoriadis, "The 'Rationality' of Capitalism", Op. cit., p. 115. Emphasis mine.

[113] This divergence of defining values is visible to most intelligent observers but neoliberals, whose agenda yet dominates institutional decision-making. Jurist Aulis Aarnio, whilst talking about interpretation of statutes in the Finnish legal system, states plainly: "Environmental values and economic values often clash, as in the protection of the forests and waterways. Almost without exception, the values that have prevailed have been economic." ["Statutory Interpretation in Finland", in D. N. MacCormick and R. S. Summers (eds.), Interpreting Statutes. A Comparative Study, Aldershot: Dartmouth, 1991, p. 131].

[114] In an interview entitled "The Revolutionary Force of Ecology", Castoriadis praises the growing awareness of "the havoc capitalism had wreaked upon the environment" has a better perspective to criticise contemporary capitalism than traditional Marxism [Cornelius Castoriadis, "The Revolutionary Force of Ecology", The Rising Tide of Insignificancy (The Big Sleep), p. 115].

[115] Although economists do recognise that money as such may not be the ultimate or guiding values of the individual, the expression of the individual's values is cast nevertheless in monetary terms qua money-demand aimed at purchasing the desired goods and services.

[116] See, infra alia, John McMurtry, The Cancer Stage of Capitalism, London: Pluto Press, 1999, pp. 151-79. The corresponding symbolic expression of pre-capitalist economic transaction is $\mathbf{C} \rightarrow \mathbf{\$} \rightarrow$ $\mathbf{C}^{\mathbf{1}}$, whereby money operates qua means of exchange, not as the end of the transaction, for the focus is on the commodity as usable good or service, rather as for-profit investment. Marxist scholars have different views on whether Marx ever believed possible for such a pre-capitalist economic reality to exist, but this debate is not relevant vis-à-vis my presentation of McMurtry's work and his understanding of the value conflict between capitalism and life-requirements.

[117] Contrarily to what Wilde seemed to believe in "The Soul of Man Under Socialism", McMurtry's analysis suggests that even the rich, or at least some of them, in a profit-driven economic system, are not free, for they have an obligation to maximise their capital, irrespective to the fact that an increase in earnings may have been already achieved for several years. In its institutional form, which McMurtry calls "meta programme" or "value system", this logic translates into the pursuit of endless growth of GDP, which Michael Oakeshott criticised as superstitious and Serge Latouche as irrational.

[118] For the sake of brevity, in the main text I focus only on the first plane of being, i.e. biological movement. However, I wish to remind the reader that McMurtry's conception of life entails three planes of being, i.e. biological movement, felt being and thought. All three planes admit of variations in breadth and depth. Also, I wish to highlight how McMurtry, by addressing the sphere of felt being, is also sensitive to the libidinal side of human nature, which Castoriadis, amongst others, takes seriously vis-à-vis the notion of freedom, which democracy aims at securing.

[119] John McMurtry, "What is Good? What is Bad? The Value of All Values Across Time, Place and Theories", Encyclopedia of Life Support System, Paris and Oxford: UNESCO, 6.25.5, to be released on www.eolss.net, $6.25 \cdot 5,5$ and 5.1 .

[120] Public management of resources can prove disastrous, but this becomes the case when the intended aims of public management are betrayed and the pursuit of self-maximisation develops in its stead.

[121] John McMurtry, "Principles of the Good Life: The Primary Theorems of Economic Reason", unpublished manuscript; see also an earlier version of the Well-Being Index in Value Wars. The Global Market Versus the Life Economy, pp. 155-7 and a successive one in "What is Good? What is Bad? The Value of All Values Across Time, Place and Theories", Op. cit., 6.25.5, 5.26.34.

[122] McMurtry has confirmed by e-mail the contiguity of his notion of "just form of life" and Castoriadis' "democracy", stating: also "I like Castoriadis - so much that I think I remember a great line from him: 'Philosophy calls into question the instituted representations of reality, the idols of the tribe, within the limits of an unlimited interrogation'".

[123] Jeff Noonan, Op. Cit.

[124] John McMurtry, Unequal Freedoms. The Global Market as an Ethical System, Toronto: Garamond Press, 1998, p. 376.

[125] In his famous essay, "The Tragedy of the Commons", Garrett Hardin argues that a system of 
private ownership is the only way to prevent mismanagement of commonly held resources and stresses the importance of strict legislation to avoid overpopulation and environmental pollution (Science, 162, 1968, pp. 1243-8).

[126] John McMurtry, Value Wars., pp. 101 and 104-5.

[127] On this point I must refer again to my latest two contributions to the Death and Anti-Death series edited by Charles Tandy.

[128] See Giorgio Baruchello, critical study of John McMurtry’s Value Wars, Appraisal , 4(3), 2003, pp. 147-52. I refer the reader to this work of mine for a critical assessment of McMurtry's oeuvre, which I wish merely to sketch hereby in connection with Castoriadis'.

[129] John McMurtry, Value Wars, pp. 48-52.

[130] Ibid., p. 54.

[131] Ibid., pp. 48-55. Margret Thatcher's catchphrase "There is no alternative", derided by many commentators of her time as "TINA", has indeed become a given of today's dominant mindset amongst world leaders.

[132] Ibid., pp. 90-3.

[133] Ibid., p. 261, 72n.

[134] Ibid., p. 96.

[135] Ibid., p. 245, 6on and pp. 162-4.

[136] Ibid., pp. 172-7.

[137] Ibid., pp. 193-8.

[138] Ibid., p. 113.

[139] Ibid., p. 245, 6on.

[140] Ibid., pp. 165-9b, 202-5, 214-5, 227, 38n and 259-6o, 66n.

[141] Ibid., pp. 181-6, 214-5.

[142] Ibid., p. 204.

[143] Ibid., pp. 165-7, 172-7, 214-9.

[144] Ibid., pp. 186-8.

[145] Ibid., pp. 150-4.

[146] Ibid., pp. 161-77.

[147] Ibid., pp. 150-4.

[148] On these issues, Castoriadis wrote: "Constantly increasing energy wastefulness is, moreover, organically incorporated into contemporary capitalism, into its economy, up to and including the psychism of individuals. I know of ecologists who don't turn off the light when leaving a room." (Cornelius Castoriadis, "Unending Interrogation", Op. cit., pp. 271-2).

[149] John McMurtry, Value Wars, pp. 198-202.

[150] My fears have not a primarily heuristic function, as Hans Jonas said of his own ones in his most famous book (Das Prinzip Verantwortung. Versuch einer Ethik für die technologische Zivilisation, Frankfurt am Main: Insel, 1979; Engl. Trans. by H. Jonas with the collaboration of D. Herr, The Imperative of Responsibility. In Search of an Ethics for the Technological Age, Chicago: The University of Chicago Press, 1984). They are genuine. They have a deep connection with the dramatic depiction of planetary reality provided by the United Nations themselves and, repeatedly, by numerous panels of experts worldwide. The denial of the widespread and far-reaching depletion of the Earth's life support systems would be absurd, if the neoliberal paradigm were not so widespread and far-reaching as well, thus diluting the official language of governments and public bodies, seizing universities and independent research centres by means of privatisation and private sponsorship, and stupefying even the most educated by its defining superstitious dogma whereby only more of the same medicine can resolve our problems, as though God's invisible hand were really at work behind the havoc we bring upon ourselves. 